\title{
Molecular Basis of Adrenal Insufficiency
}

\author{
KENJI FUJIEDA AND TOSHIHIRO TAJIMA \\ Department of Pediatrics [K.J.], Asahikawa Medical College, Asahikawa 078-8510, Japan, Department of \\ Pediatrics [T.T.], Hokkaido University School of Medicine, Sapporo 060-0835, Japan
}

\begin{abstract}
Defective production of adrenal steroids due to either primary adrenal failure or hypothalamic-pituitary impairment of the corticotrophic axis causes adrenal insufficiency. Depending on the etiologies of adrenal insufficiency, clinical manifestations may be severe or mild, have gradual or sudden onset, begin in infancy or childhood/adolescence. Adrenal crisis represents an endocrine emergency, and thus the rapid recognition and prompt therapy for adrenal crisis are critical for survival even before the diagnosis is made. The recognition of various disorders that cause adrenal insufficiency, either at a clinical or molecular level, often has implications for the management of the patient. Recent molecular-genetic analysis for the disorder that causes adrenal insufficiency gives valuable insights into the adrenal organogenesis, the regulation of steroid hormone biosynthesis, and the developmental and reproductive endocrinology. In this review we present the latest information on the molecular basis of adrenal insufficiency, with special emphasis on congenital lipoid adrenal hyperplasia, P450-oxidoreductase deficiency, and adrenal hypoplasia congenita. (Pediatr Res 57: 62R-69R, 2005)
\end{abstract}

ABSTRACT

\author{
ABS, Antley-Bixler syndrome \\ AHC, adrenal hypoplasia congenita \\ AIRE, autoimmune regulator \\ CAH, congenital adrenal hyperplasia \\ DAX-1(NR0B1), dosage-sensitive sex reversal-adrenal \\ hypoplasia congenita critical region on the X-chromosome, \\ gene-1 \\ P450sce, cholesterol desmolase (cholesterol side chain \\ cleavage enzyme) \\ POR, P450-oxidoreductase \\ SF-1(NR5A1), steroidogenic factor-1 \\ StAR, steroidogenic acute regulatory protein \\ TPIT, T-box factor pituitary \\ triple A syndrome, Achalasia-Addisonianism-Alacrima \\ syndrome
}

The recognition of various disorders that cause adrenal insufficiency, either at a clinical or molecular level, often has implications for the management of the patient. Recent molecular-genetic analysis for the disorder that causes adrenal insufficiency gives valuable insights into adrenal organogenesis, regulation of steroid hormone biosynthesis, and the developmental and reproductive endocrinology.

In this review we present the latest knowledge on the molecular basis of adrenal insufficiency. We start with a brief overview of adrenal embryology and biochemistry and then discuss molecular pathogenesis of the disorders that cause adrenal insufficiency, with a special emphasis on congenital lipoid adrenal hyperplasia, POR deficiency, and adrenal hypoplasia congenita.

\section{ANATOMY AND EMBRYOLOGY}

The human adrenal gland is composed of two organs-the adrenal cortex and the adrenal medulla. The adrenal cortex is

Received August 11, 2004; accepted December 9, 2004.

Correspondence: Kenji Fujieda, M.D., Ph.D., Department of Pediatrics, Asahikawa Medical College, 2-1-1-1, Midorigaoka, Higashi, Asahikawa 078-8510, Japan; e-mail: ken-fuji@asahikawa-med.ac.jp functionally defined by the presence of three distinct cell layers categorized by the expression of specific steroidogenic enzymes and the ability to respond to specific peptide hormones, outer zona glomerulosa, central zona fasciculata, and inner zona reticularis. The human fetal adrenal possesses a transient developmental zone between the functional cortical zones and the medulla-fetal zone.

Recent mouse and human genetic studies have begun to unravel the complex genetic cascade on the organogenesis of the human adrenal gland. The factors that regulate adrenocortical organogenesis and the maintenance of growth promotes or blocks a cascade of transcription factors that differentially coordinate the proliferation and differentiation of the adrenal gland. Important transcriptional factors required for organogenesis and the maintenance of growth of the adrenal cortex are shown in Figure $1(1-7)$. The human adrenal cortex appears at $\mathrm{d} 25$ postconception as a blastema of undifferentiated cells of mesodermal origin from a condensation of coelomic epithelial cells on the urogenital ridge (8). This condensation of coelomic epithelial cells on the urogenital ridge results also in the formation of the kidney and gonadal structures. After contact with primordial germ cells, the fetal adrenal (composed of fetal 


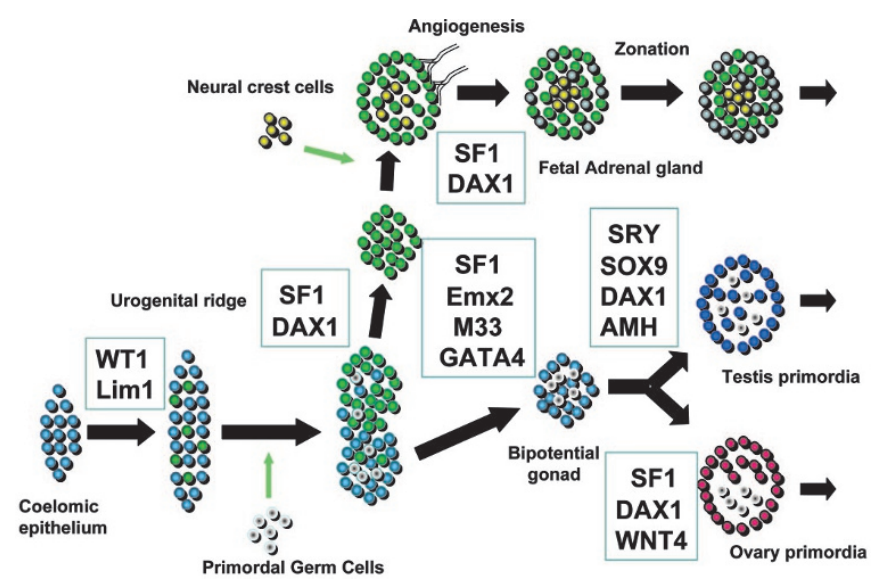

Figure 1. Simplified schematic presentation of organogenesis of adrenal gland.

zone and definitive zone) and bipotential gonadal cells then separate. At approximately wk 8, the adrenal gland continues to develop as the neural crest cells that will ultimately become the adrenal medulla migrate to the center of the gland. During the second trimester, the fetal zone enlarges and becomes larger than the kidney. The fetal zone with expression of the steroidogenic enzymes produces dehydroepiandrosterone for placental conversion to estriol in the maternal circulation. Shortly after birth, this fetal zone shows involution and the process of adult-type cortical zonation from the thin definitive zone is initiated. The definitive zone starts differentiating into its glomerular and fascicular parts as early as embryonic wk 28. The zona reticularis does not appear until the end of y 3 of life. The triggers that initiate these changes remain unclear (9). For survival and maintenance of the adrenal medulla, high concentrations of glucocorticoids from the adrenal cortex are required (10).

WT1 is appreciated as a crucial gene that specifies kidney, gonadal, and adrenal cell lineages (4). This dictates the specification of the metanephric kidney and adreno-gonadal primordium. Two transcription factors, SF-1 and DAX-1, play an important role for the development and differentiation of adreno-gonadal primordium that gives rise to the adrenal cortex and gonads $(1,2,4,7)$. The bipotential gonad goes on to differentiation into a testis or ovary depending on the genetic sex and through the action of several transcription factors such as SRY, SOX9, AMH, SF-1, DAX-1, and WNT4 (1,2,5,7). As such, various transcriptional pathways by which it dictates adrenal gland development and maintenance are undoubtedly diverse. Ontogenic regulation of these critical developmental pathways is postulated to require cell- and time-dependent regulation of transcriptional factors, co-regulators, hormones, and downstream targets that remain disclosed.

\section{BIOCHEMISTRY}

The human adrenal cortex secretes three principal classes of steroid hormones: mineralocorticoids, glucocorticoids, and sex steroids. The biosynthesis of these hormones is initiated by the utilization of available free plasma cholesterol or stored pools of labile cholesterol. Most of its cholesterol comes from low density lipoproteins (LDL). The uptake of LDL-cholesterol by adrenal cells is promoted by ACTH. The conversion of cholesterol to the steroid molecule, pregnenolone, a precursor steroid, requires biochemical reactions, including StAR, hydroxylation of C20 and C22 of cholesterol, followed by cleavage of the $20 \alpha$ and 22 side chains of dihydroxycholesterol by a single enzyme, cholesterol desmolase (cytochrome P450 cholesterol side-chain cleavage enzyme, P450scc). This ratelimiting step also requires the transport of the electron by adrenodoxin reductase and adrenodoxin to P450scc for oxidation in the inner membrane of the adrenal mitochondria. Pregnenolone is then converted to mineralocorticoids, glucocorticoids, and sex steroids by a complex of biochemical events activated by enzymatic actions of $3 \beta$-hydroxysteroid dehydrogenase, P450c17, P450c21, P450c11, and others. P450 oxidoreductase has an important role for electron transfer from NADPH to P450c17 and P450c21 and other microsomal P450 enzymes $(11,12)$.

\section{ETIOLOGIES OF ADRENAL INSUFFICIENCY}

The various etiologies of adrenal insufficiency can be subgrouped into three categories: 1) impaired steroidogenesis, 2) adrenal dysgenesis/hypoplasia, and 3) adrenal destruction. Genetic causes of adrenal insufficiency are shown in Table 1. Adrenal insufficiency of CAH, Wolman disease, Smith-LemliOpitz syndrome, and mitochondrial disorders can result from either enzymatic defects in steroidogenesis or cholesterol metabolism. POR deficiency was recently identified and classified as a new form of CAH that causes apparent combined P450c17 and P450c21 deficiency (13-15). Adrenal hypoplasia congenita, mutations of SF-1 (16), and ACTH insensitivity syndrome and ACTH deficiency can be all lead to adrenal dysgenesis/hypoplasia, albeit the latter of the two disorders usually result in isolated deficiency of glucocorticoids. Autoimmune polyglandular syndrome (APS), adrenoleukodystrophy (ALD) and nongenetic insults such as adrenal hemorrhage and infections can cause destruction of the adrenal gland.

Depending on the etiologies, adrenal crisis may occur in early infancy or symptoms of adrenal insufficiency may insidiously develop in childhood/adolescence. Acute adrenal crisis is more likely to occur if the child with undiagnosed chronic adrenal insufficiency is subjected to situations of major stress such as acute illness, surgery, and injury.

The leading causes of adrenal insufficiency today are congenital enzymatic defects for steroid biosynthesis.

\section{CONGENITAL ADRENAL HYPERPLASIA}

$\mathrm{CAH}$ is a group of diseases whose common features are an enzymatic defect in the steroidogenesis pathway. Patients with $\mathrm{CAH}$ frequently present symptoms due to glucocorticoid and mineralocorticoid deficiency. Additional clinical features may include ambiguous genitalia in girls and boys, hypertension, and XY sex reversal. The most frequent is 21-hydroxylase deficiency, accounting for more than $90 \%$ of cases (17). Mutations or deletions of genes of P450scc or StAR, 3 $\beta$ hydroxysteroid dehydrogenase, $17 \alpha$-hydroxylase, and $11 \beta$ hydroxylase also causes CAH. The mutations in POR, the 
Table 1. Genetic causes of adrenal insufficiency

\begin{tabular}{|c|c|c|c|}
\hline Disorder & Gene & Chromosomal location & $\begin{array}{c}\text { Mendelian Inheritance in Man } \\
\text { (OMIM\#) }\end{array}$ \\
\hline \multicolumn{4}{|l|}{ Congenital adrenal hyperplasia } \\
\hline Lipoid CAH & StAR, CYP11A & $8 \mathrm{p} 11.2,15 \mathrm{q} 23-24$ & 201710 \\
\hline P450c17 deficiency & CYP17 & $10 \mathrm{q} 24.3$ & 202110 \\
\hline P450c21 deficiency & CYP21 & $6 \mathrm{p} 21.3$ & 201910 \\
\hline P450c11 deficiency & CYP11B1 & $8 \mathrm{p} 21$ & 202010 \\
\hline Smith-Lemli-Opitz syndrome & DHCR7 & $11 q 12-q 13$ & 270400 \\
\hline Mitochondrial disease & Mt DNA & & \\
\hline \multicolumn{4}{|l|}{ Adrenal hypoplasia congenita (AHC) } \\
\hline $\mathrm{X}$-linked AHC & DAX-1(NROB1) & $\mathrm{Xp} 21.3-\mathrm{p} 21.2$ & 300200 \\
\hline SF-1 linked AHC & SF-1(NR5A1) & $9 q 33$ & 184757 \\
\hline Autosomal recessive AHC & Unknown & & \\
\hline \multicolumn{4}{|l|}{ ACTH insensitivity syndrome } \\
\hline Familial glucocorticoid deficiency 1 & MC2R, others & $18 \mathrm{p} 11$ & 607397 \\
\hline Triple A syndrome & AAAS, ALADIN & $12 \mathrm{q} 13$ & 231550 \\
\hline \multicolumn{4}{|l|}{ Autoimmune adrenal insufficiency } \\
\hline APS1 & AIRE-1 & $21 \mathrm{q} 22.3$ & 270400 \\
\hline APS2 and isolated adrenalitis & HLA class II, CTLA-4, others & $6 \mathrm{p} 21,2 \mathrm{q} 33$ & \\
\hline Adrenoleukodystrophy & ALD & $\mathrm{Xq} 28$ & 300100 \\
\hline
\end{tabular}

flavoprotein that donates electron to microsomal P450 enzymes, is also responsible for combined partial deficiency of $17 \alpha$-hydroxylase and 21-hydroxylase activities. Several excellent reviews for $\mathrm{CAH}$ are now available $(11,12,17)$. Thus, we discuss here the latest knowledge for molecular pathogenesis of lipoid $\mathrm{CAH}$ and $\mathrm{P} 450$ oxidoreductase deficiency.

\section{LIPOID CAH}

$\mathrm{CAH}$ - lipoid CAH is the most severe form-may be caused by mutations of StAR and P450scc genes $(18,19)$. As P450scc and StAR are expressed in both adrenal and gonads, lipoid $\mathrm{CAH}$ disrupts the synthesis of all adrenal and gonadal steroids and leads to the accumulation of cholesterol esters. The true incidence of lipoid CAH is unknown, however, it is clearly much higher in Japanese, Korean, and Palestinian populations. It was long thought that lipoid CAH was caused by P450scc defects. However, StAR, which functions as a labile protein factor in steroidogenesis mediating cholesterol transport within mitochondria was identified as a cause of lipoid CAH instead of P450scc at first $(18,20,21)$, but recently two patients with P450scc gene mutations were found $(19,22)$. Thus, both defects of StAR and P450scc may cause lipoid CAH, but mutations of StAR would account for most cases of lipoid CAH.

Affected individuals with lipoid $\mathrm{CAH}$ are phenotypically female and have severe salt wasting. Symptoms of adrenal insufficiency usually manifest during the neonatal and early infantile period. None of the patients with a 46, XY individual manifest any pubertal changes despite their chronological age. By contrast, patients with a 46, XX individual manifest secondary sexual characteristics with the development of breast tissue, pubic hair, and irregular menstruation (23). Ovaries in postpubertal stage are enlarged with many cysts occupying the entire volume of the ovary and hypertrophied ovarian stroma. In contrast, ovaries in the prepubertal stage are normal size and there is no cystic change, indicating that ovarian steroidogenic tissues are spared to some extent the early and persistent stimulation that dooms the testicular and adrenal cortical cells to damage from cholesterol engorgement $(20,23)$. The two-hit model of lipoid $\mathrm{CAH}$ for the pathogenesis is proposed and confirmed both by clinical observation and by studies with StAR knockout mice $(20,23,24)$. This model results from low initial levels of StAR-independent steroidogenesis (the first hit), leading to a complete loss of steroid hormones due to cellular destruction by accumulated lipids (the second hit) (20).

So far, more than 34 different mutations in the StAR gene have been identified $(18,20,21)$. Among them, the Q258X in exon 7 is very common in Japanese and Korean population (over $80 \%$ ), suggested by a Korean origin of the disorder in Japanese patients. Functional studies on StAR mutants protein demonstrated most of the mutations severely impaired StAR protein function. However, one missense mutation, M225T was shown to retain $43 \%$ of activity of the wild-type StAR protein (21). The patient who was compound heterozygous for M225T and Q258X mutations showed adrenal insufficiency at 10 mo. The karyotype of this patient is $46, \mathrm{XY}$ and external genitalia showed mild virilization. Thus, her clinical phenotype including genital virilization can be explained by the mild genotype of StAR gene as assessed in vitro.

Manifestations of two individuals with P450sce mutations were atypical for lipoid CAH. The first patient survived for $4 \mathrm{y}$ without hormonal replacement and was diagnosed as having adrenal insufficiency by lethargy and hyperpigmentation (19). 
Clitoromegaly and labial fusion were also found. The second patient was a 46, XX female patient (22). She was followed by increased pigmentation at 3 mo of age, and diagnosed as having adrenal insufficiency at 7 mo of age by increased ACTH, inappropriately low cortisol, and elevated plasma renin activity. The mutation of P450sccc gene in the first patient was a heterozygous in-frame insertion of Gly and Asp, completely inactivating enzymatic activity. The second patient was a compound heterozygote for two mutations. One mutation was R355W that markedly reduced P450scc activity. Another mutation was A189V. This amino acid change did not affect the enzymatic activity, but created a novel alternative splice donor site, resulting in a deletion of 61 nucleotides in the open reading frame and thus partially inactivated enzymatic activity.

\section{POR DEFICIECNY}

POR deficiency is a new disorder of adrenal and gonadal steroidogenesis that affects all microsomal cytochrome $\mathrm{P} 450$ enzymes. The POR is flavoprotein that donates electrons to all microsomal forms of cytochrome P450 (13). The mutations of POR cause partial deficiencies in steroid $17 \alpha$-hydroxylase, 17 , 20 lyase, and 21-hydroxylase with and without ABS (OMIM 207410). ABS is characterized by craniosynostosis, radio/ humeral synostosis, ambiguous genitalia, and other congenital anomalies. In addition, some patients with ABS showed abnormal steroid hormone profiles of elevated serum 17hydroxyprogesterone and low cortisol levels (25-27). These endocrine findings have strongly suggested that there is a genetic defect of steroid biosynthesis in ABS. Mutations in the IgIII domain of the fibroblast growth factor receptor 2 (FGFR2) gene, also causing other craniosynostosis syndromes have been reported in some ABS patients, however, these patients with FGFR2 mutations do not have the steroidogenic abnormalities (25-27). Finally, steroidogenic abnormalities in ABS are answered. Subsequent reports on clinical analysis in the patients with POR mutation characterized that these patients have normal-to-poor masculinization during fetal and pubertal periods in male patients, virilization during fetal life and poor pubertal development without worsening of virilization in female patients, and relatively large height gain and delayed bone age from the pubertal period in patients of both sexes, together with maternal virilization during pregnancy $(14,15)$ However, the reason why POR mutations develop ABS phenotype and other clinical features is unknown. Microsomal P450 system is responsible for the metabolism of many exogenous products (toxins, drugs, and xenobiotics) and endogenous products such as steroids, fatty acids, and prostaglandins (11). Retinoic acid, the active metabolite of vitamin A, is also metabolized by microsomal cytochrome P450, CYP26, and plays a key role in vertebrate embryo organogenesis (28). It is known that an excess of retinoic acid induces craniofacial, heart, and limb defects (29). Thus, it is plausible that POR mutations cause retinoic acid excess in embryos, resulting in skeletal abnormality. Other environmental teratogens metabolized by P450-POR system may be affected by reduced POR activity. It is interesting to note that POR denote electrons to the microsomal forms of cytochrome P450 such as P450c21,
P450c17, P450c19, and P450c51. Thus, partial deficiency of these P450 enzymes caused by the mutation of POR may be responsible for the various clinical phenotypes of $\mathrm{ABS}$ with adrenal insufficiency $(14,15)$. Among the mutations in the POR gene, $\mathrm{R} 457 \mathrm{H}$ mutation is the most frequent in Japanese patients and a founder effect was suggested.

\section{ADRENAL HYPOPLASIA CONGENITA}

AHC is an inherited disorder that most often presents saltlosing adrenal crisis during the neonatal period or during childhood. This disorder can present as three clinical forms of primary adrenal insufficiency: 1) a sporadic form associated with pituitary hypoplasia, autosomal recessive form with TPIT gene mutation and genetic form of combined pituitary hormone deficiency; 2) an autosomal recessive form with a distinct miniature adult adrenal morphology, characterized by small glands with a permanent cortical zone but a diminished fetal zone; and 3) an X-linked cytomegalic form associated with hypogonadotropic hypogonadism and an X-linked form associated with glycerol kinase deficiency. Two major histologic types of congenital adrenal hypoplasia have been described in relation to fetal zone and definitive zone of fetal adrenal gland: the cytomegalic form and the miniature adult form. The miniature adult form of congenital adrenal hypoplasia is less common and is thought to be autosomal recessive because it has been reported in both male and female siblings. This form is characterized by miniature adult adrenal glands with a permanent cortical zone but a diminished fetal zone. The molecular basis of this form is still unclear.

\section{X-LINKED AHC}

The adrenal glands in this form lack the definitive zone of the adrenal cortex and are characterized by large vacuolated cells resembling fetal adrenocortical cells. It is called cytomegalic form. Hypogonadotropic hypogonadism (HHG) is a feature of this form. X-linked AHC also occurs as part of a contiguous deletion syndrome together with Duchenne muscular dystrophy and/or glycerol kinase deficiency.

DAX-1(NR0B1) gene mapped to Xp21 is responsible for $\mathrm{X}$-linked AHC $(2,30)$. DAX-1 gene consists of two exons separated by a $3.4 \mathrm{~kb}$ intron. DAX-1 encodes an orphan member of the nuclear hormone receptor super-family that lacks the typical zinc finger DNA-binding motif in the Nterminus but retains the ligand-binding domain in the Cterminus characteristics of other nuclear hormone receptor super-family. Instead of the zinc-finger domain, the N-terminal consists of three repeats of 65 to 67 amino acid motifs, each containing an LXXLL-related motif (31). This motif was originally identified in the nuclear receptor co-activators and is crucial for interaction with nuclear receptors (32).

As DAX-1 protein is expressed in the adrenal cortex, testis, ovary, anterior pituitary, and hypothalamus, DAX-1 is considered to play important roles for the development and function for not only adrenal but also the hypothalamic-pituitarygonadal axis (33). This expression pattern accounts for the clinical features of this disorder. 
It has been demonstrated that DAX-1 has a wide variety of functions. DAX-1 acts as transcriptional repressor for SF-1 and genes involved in steroid hormone metabolism (34-36). DAX-1 is also a nucleocytoplasmic shuttling protein associated with ribonucleoprotein structures in the nucleus and polyribosomes in the cytoplasm (37). These findings suggest the regulatory function in the posttranscriptional process.

As mentioned, HHG is a characteristic feature of this disorder. Affected boys who reach postpubertal age will fail to undergo puberty, even if in early infancy the pituitary-gonadal axis may be intact $(38,39)$. The cause of HHG is now considered to be a result of hypothalamic GnRH or pituitary LH and FSH defect or both. Spermatogenesis in this disorder is also affected. In our experience, long-term hCG treatment increased serum testosterone levels, but evidence of spermatogenesis was not obtained by hCG-HMG administration (40). Testicular biopsy revealed Sertoli cell hypoplasia, no sperm formation, and Leydig cell hyperplasia. These findings are consistent with other reports $(41,42)$. In Ahch (the mouse DAX-1 homologue) knockout mice, spermatogenesis was impaired (43). Furthermore, Sertoli cell-specific expression of human DAX-1 transgene in Ahch knockout mice could restore fertility to some degree (44), suggesting that DAX-1 may be critical for spermatogenesis in Sertoli cells.

To date, gene deletions and more than 80 different mutations of the DAX-1, including frameshift, nonsense, and missense mutations, have been identified in human with X-linked AHC $(30,40-42,45-49)$. The majority of the mutations are frameshift and nonsense mutations, being distributed throughout the DAX-1 coding region. Seventeen missense mutations are now identified and located only in the C-terminal putative ligand binding domain, and these missense mutations have been reported to impair the transcriptional repression activity $(40,43,49-52)$. One missense mutation (L466R), which is located in the activation function 2 (AF2) core of a highly conserved region in the $\mathrm{C}$-terminus, was shown to be defective in nuclear localization in spite of having an intact $\mathrm{N}$-terminus and to impair the repression activity of DAX-1 (31). It has been also observed that several mutants from patients with AHC cannot localize into the nucleus, and thus this would partly explain the loss of function $(53,54)$.

In this disorder, there is a phenotypic heterogeneity in both adrenal failure and HHG. Clinical presentation of adrenal insufficiency is recognized to be variable even within a family. Several boys showed adrenal crisis in infancy, but others had an insidious progress of adrenal insufficiency during childhood/adolescence $(30,43,47,50,52)$. Regarding HHG, some patients showed spontaneous puberty $(40,42,43,55)$. One may consider the phenotype-genotype correlation like other genetic disorders. To evaluate the relation between clinical severity of adrenal insufficiency and HHG, we constructed the expression vector of mutant DAX-1 of Y91X, V269D, Y271X, L278R, W291C, K382N, Q395X, and L466R from patients and analyzed the inhibition activity to promoter of StAR and $\mathrm{LH} \beta$ genes (40). The wild-type DAX-1 suppressed the activation of SF-1-mediated StAR gene promoter and SF-1/Egr-1-mediated $\mathrm{LH} \beta$ gene promoter, but each of the DAX-1 mutants could not repress these activations. However, the degree of transcrip- tional inhibition was not related to the onset of adrenal insufficiency and spontaneous development of puberty. Several studies also demonstrated that there was no clear correlation among clinical phenotype, genotype, and abolishment of transcription inhibitory activity in vitro $(49,52)$. However, I493S possessing intermediate levels of repressor activity of DAX-1 have been reported to cause mild adrenal insufficiency and spontaneous puberty (42). As DAX-1 has a wide variety of functions at multilevel and developmental stages, other genetic and epigenetic factors may modify the phenotype, in addition to the genotype of DAX-1.

\section{SF-1-LINKED AHC}

SF-1 is an orphan nuclear receptor involved in the regulation of steroidogenesis, reproduction, and male sexual differentiation. The targeted disruption of this gene in mice results in adrenal and gonadal aplasia and XY sex reversal in homozygotes (1). In humans, six cases with SF-1 mutations have been reported. Human phenotype is suggested to be different from mice phenotype. Only three cases manifested adrenal insufficiency, implying that SF-1 mutations are not likely to account for many cases of inherited adrenocortical insufficiency. At first, neonatal primary adrenal failure and XY sex reversal has been described as phenotypically female, due to a heterogeneous 2-bp mutation in the DNA binding domain of SF-1 (16). The adrenal morphology in this case remains unknown. In the second case, the patient was $46, \mathrm{XX}$ prepubertal phenotypically normal female with adrenal insufficiency. She was homozygous for a missense mutation in the A box. Heterozygous relatives of this proband had normal adrenal function. The third case is a 46, XY infant homozygous for a R92Q mutation, who showed both adrenal insufficiency and sex reversal. Three other cases with heterozygous either deletion or nonsense mutation did not present adrenal insufficiency, showing only ambiguous genitalia.

\section{IMAGE SYNDROME}

This syndrome is characterized by intrauterine growth retardation, metaphyseal dysplasia, adrenal hypoplasia congenita, and genital anomalies. DNA sequence analysis found no mutations in the coding regions of either DAX-1 or SF-1. This suggests IMAGe syndrome results from a novel gene that plays important roles in the development of bone, the adrenal cortex, and the anterior pituitary (56).

\section{ACTH DEFICIENCY}

Congenital isolated ACTH deficiency (IAD) is a rare inherited disorder that is clinically and genetically heterogeneous. Patients are characterized by low or absent cortisol production secondary to low plasma ACTH despite normal secretory indices of other pituitary hormones and the absence of structural pituitary defects. Onset may occur in the neonatal period, but may first be observed in later children. Candidate genes for ACTH deficiency include POMC, PC1, CRH, and its receptor (CRH-R1) (57,58). However, mutations in these genes have not been reported to be associated with IAD. Linkage of the 
CRH gene locus to IAD has been observed in one family, no mutations in this gene or its receptor have been described in humans, implying that other genes/pathways must be involved in this disease. The differentiation of pituitary cell types during embryonic development is regulated by the combined action of a subset of tissue- and cell-restricted transcription factors $(59,60)$. Two such factors have been reported in the POMCexpressing lineages of the pituitary, NeuroD1 and TPIT. NeuroD1 contributes to cell-specific transcription of the POMC gene in corticotroph cells and is required for early corticotroph differentiation. Defects in NeuroD1 are a cause of maturity onset diabetes of the young. TPIT is a member of the T-box gene family, the defining feature of which is a region of conserved DNA sequence (the T-box) that encodes a DNA binding domain. TPIT is a highly cell-restricted transcription factor that is required for expression of the pro-opiomelanocortin (POMC) gene and for the terminal differentiation of the pituitary corticotroph lineage (60). TPIT expression is restricted to the two pituitary POMC-expressing lineages in mice, the corticotrophs and melanotrophs. TPIT deficiency is likely to only affect pituitary POMC production directly. The mutations in the TPIT gene are associated at high frequency with early onset IAD, but not with late-onset IAD (61). This congenital early-onset IAD is caused by recessive transmission of loss-of-function mutations in the TPIT gene. Neonatal hypoglycemia was the major reason leading to diagnosis of ACTH deficiency. They had very similar clinical presentations that included severe plasma ACTH and cortisol deficits, episodes of sudden and severe hypoglycemia sometimes associated with seizures, episodes of prolonged neonatal cholestatic jaundice, and neonatal death when untreated. No phenotypic differences between early-onset IAD cases with and without mutations were apparent. The finding that no late-onset patients have mutations in TPIT is highly suggestive of the involvement of at least one other gene in this disorder. Most human cases of congenital ACTH deficiency involve other deficiencies such as in combined pituitary hormone deficiencies (59). Two cases of ACTH deficiency associated with severe obesity and red hair pigmentation have been linked to POMC gene anomalies (57). One case of ACTH deficiency with gonadotroph deficiency, severe obesity, and glycoregulation anomalies was described to a PC1 gene mutation (58).

\section{ACTH INSENSITIVITY SYNDROME}

ACTH insensitivity results from a group of rare autosomal recessive genetic defects (62). Familial glucocorticoid deficiency is one of these syndromes in which about half of all cases have inactivating mutations of the MC2 (ACTH) receptor (63). Another rare syndrome of ACTH resistance is known as Triple A syndrome or Allgrove syndrome.

\section{FAMLIAL GLUCOCORTICOID DEFICIENCY}

The MC2R is a member of the G protein-coupled receptor superfamily that mediates the effects of ACTH on the adrenal cortex. Patients with familial glucocorticoid deficiency usually present early with typical symptoms of only cortisol deficiency such as weakness, hypoglycemia, and hyperpigmentation. His- tologically, the zonae fasciculate/reticularis are almost completely atrophied, where the zona glomerulosa appears intact. A number of mutations of the MC2R gene have been identified in some of these patients, but not all (63). The remaining 60\% of patients with this syndrome have defects in one or more other as yet unidentified genes that are unlinked to the MC2R receptor. Segregation studies exclude linkage to the ACTH receptor region in several kindred. This demonstration of genetic heterogeneity suggests that two distinct forms of FGD are likely to exist. Recently, a gene encoding a new interacting partner of the ACTH receptor was identified to be responsible for familal glucocorticoid deficiency type 2 (64).

\section{TRIPLE A OR ALLGROVE SYNDROME}

This rare condition is associated with the triad of adrenal insufficiency due to ACTH resistance, achalasia of the cardia, and alacrima. Other features include autonomic and/or peripheral neuropathy. Recently, the responsible gene for the triple A syndrome was cloned (AAAS gene) (65). The AAAS gene encodes a 546 amino acid protein called ALADIN (AlacrimaAchalasia-aDrenal Insufficiency Neurologic disorder) and contains four WD repeat motifs. The mutations in the AAAS gene were identified only in the patients with this syndrome but not in the patients with isolated ACTH resistance. There is significant clinical variability between patients with the same AAAS defect (66). ALADIN may be important for a cell type-specific role in regulating nucleocytoplasmic transport nuclear pore complexes (67), but the exact mechanism causing variable symptoms has not been clarified.

\section{AUTOIMMUNE ADRENAL FAILURE}

Autoimmune destruction of the adrenal glands remains the primary etiological mechanism of adrenal failure in the Western population. However, this condition is quite rare in other populations, such as the Japanese, implying there is a difference in susceptibility for this condition among the races.

Addison disease is a prototype of primary acquired adrenal insufficiency. In the early part of the century, tuberculous adrenalitis was the most prevalent cause of adrenal insufficiency. In more recent years, $80-90 \%$ of patients with Addison disease have autoimmune adrenalitis, which can occur as either a clinically isolated form or in association with other autoimmune polyglandular syndrome (APS) type 1 and type 2 $(68,69)$. APS type 1 , also termed autoimmune polyendocrinopathy candidiasis ectodermal dystrophy (APECED) arises in up to $15 \%$ of patients with autoimmune adrenalitis. This is a monogenic disorder with autosomal recessive inheritance, affecting both sexes with equal prevalence. It is relatively common in the Finnish population and Iranian Jews.

Patients with APECED usually develop within their childhood and teenage years. Usually the first sign of the syndrome is chronic Candida infection, followed by autoimmune hypoparathyroidism and adrenal insufficiency. At least two of these three major components need to be present for diagnosis. Other features in APS1 include type1 diabetes, primary gonadal failure, pernicious anemia, chronic active hepatitis and hypothyroidism. Hypoparathyroidism, appearing within the first 
decade of life, is the most frequent, and sometimes the only endocrine disease seen in APECED patients. Hypoparathyroidism is often followed by adrenocortical insufficiency, with an age at onset of about 11-15 y.

This disorder is caused by mutations in the AIRE gene $(70,71)$, which encodes a 545 amino acid protein that has two plant homeodomain (PHD)-type zinc-finger motifs. More than 50 different mutations have been described in patients who have APS1, and the defects include nonsense and missense mutations, small insertions and deletions that lead to frameshift, and splice mutations. Recent knockout mice study demonstrated that AIRE is important for autoimmunity by regulating the transcription of peripheral tissue-restricted antigens in thymic medullary epithelial cells (72). Immunologically, the main finding in APECED patients is the presence of autoantibodies against the affected organs, including those against steroidogenic enzymes such as P450scc, P450c17, and $\mathrm{P} 450 \mathrm{c} 21$ in patients with adrenal insufficiency, glutamic acid decarboxylase in patients with diabetes and the enzymes aromatic L-amino acid decarboxylase and P4501A2 in patients with liver disease $(73,74)$.

The autoimmune polyendocrinopathy type 2 (APS2, Schmidt) syndrome is the association of adrenal failure with autoimmune thyroid disease and/or type 1 diabetes, This has a predilection for middle-aged females, with an average age of onset between 35 and $40 \mathrm{y}$. The genetic basis of isolated autoimmune adrenalitis and APS2 has been less clearly defined.

\section{PERSPECTIVES}

The genetic approach in humans has allowed progress in the understanding of the mechanism of adrenal diseases. Many questions remain, however. What is the exact mechanism of the adrenal zonation? Is there any stem cell reproducing all cortical cells in three different zones? What genes or pathways can trigger the fetal adrenal degradation and the development for adult adrenal cortex? What is the mechanism by which the defective AIRE gene causes an aberrant immune response? In the near future, there is little doubt that these questions will be solved. This, in turn, could provide useful tools for the development new therapeutic strategies for long-term management of adrenal diseases.

\section{REFERENCES}

1. Luo X, Ikeda Y, Parker KL 1994 A cell-specific nuclear receptor is essential for adrenal and gonadal development and sexual differentiation. Cell 77:481-490

2. Zanaria E, Muscatelli F, Bardoni B, Strom TM, Guioli S, Guo W, Lalli E, Moser C Walker AP, McCabe ER, Meitinger T, Monaco AP, Sassone-Corsi P, Camerino G 1994 An unusual member of the nuclear hormone receptor superfamily responsible for X-linked adrenal hypoplasia congenita. Nature 372:635-641

3. Miyamoto N, Yoshida M, Kuratani S, Matsuo I, Aizawa S 1997 Defects of urogenital development in mice lacking Emx2. Development 124:1653-1664

4. Nachtigal MW, Hirokawa Y, Enyeart-Van Houten DL, Flanagan JN, Hammer GD, Ingraham HA 1998 Wilms' tumor 1 and Dax-1 modulate the orphan nuclear receptor SF-1 in sex-specific gene expression. Cell 93:445-454

5. Jeays-Ward K, Hoyle C, Brennan J, Dandonneau M, Alldus G, Capel B, Swain A 2003 Endothelial and steroidogenic cell migration are regulated by WNT4 in the developing mammalian gonad. Development 130:3663-3670

6. Schnabel CA, Selleri L, Cleary ML $2003 \mathrm{Pbx} 1$ is essential for adrenal development and urogenital differentiation. Genesis 37:123-30

7. Keegan CE, Hammer GD 2002 Recent insights into organogenesis of the adrenal cortex. Trends Endocrinol Metab 13:200-208
8. Messiano S, Jaffe RB 1996 Development and function of the primate fetal adrenal cortex. Endocrine Rev 1:663-671

9. Vinson GP 2003 Adrenocortical zonation and ACTH. Microsc Res Tech 61:227-239

10. Ehrhart-Bornstein M, Hinson JP, Bornstein SR, Scerbaum WA, Vinson GP 1998 Intraadrenal interactions in the regulation of adrenocortical steroidogenesis. Endocr Rev 19:101-143

11. Miller WL 1998 Molecular biology of steroid hormone synthesis. Endocrinol Rev 9:285-318

12. New MI 2003 Inborn errors of adrenal steroidogenesis. Mol Cel Endocrinol 211:75-83

13. Fluck CE, Tajima T, pandey AV, Arlt W, Okuhara K, Verge CF, Jabs EW, Mendonca BB, Fujieda K, Miller WL 2004 Mutant P450 oxidoreductase causes disordered steroidogenesis with and without Antley-Bixler syndrome. Nat Genet 36:228-230

14. Arlt W, Walker EA, Draper N, Ivison HE, Ride JP, Hammer F, Chalder SM, Borucka-Mankiewicz M, Hauffa BP, Malunowicz EM, Stewart PM, Shackleton $\mathrm{CH}$ 2004 Congenital adrenal hyperplasia caused by mutant P450 oxidoreductase and human androgen synthesis: analytical study. Lancet 363:2128-2135

15. Fukami M, Horikawa R, Nagai T, Tanaka T, Naiki Y, Sato N, Okuya T, Nakai H, Soneda S, Tachibana K, Matsuo N, Sato S, Hom K, Nishimura G, Hasegawa T, Ogata T 2004 Cytochrome P450 oxidoreductase gene mutations and Antley-Bixler syndrome with abnormal genitalia and/or impaired steroidogenesis: molecular and clinical studies in 10 patients. J Clin Endocrinol Metab 90:414-426

16. Achermann JC, Ito M, Ito M, Hindmarsh PC, Jameson JL 1999 A mutation in the gene encoding steroidogenic factor-1 causes XY sex reversal and adrenal failure in humans. Nat Genet 22:125-126

17. Speiser PW, White PC 2003 Congenital adrenal hyperplasia. N Engl J Med 349:776788

18. Lin D, Sugawara T, Strauss JF III, Clark BJ, Stocco DM, Saenger P, Rogol A, Miller WL 1995 Role of steroidogenic acute regulatory protein in adrenal and gonadal steroidogenesis. Science 267:1828-1831

19. Tajima T, Fujieda K, Kouda N, Nakae J, Miller WL 2001 Heterozygous mutation in the cholesterol side chain cleavage enzyme (p450scc) gene in a patient with 46,XY sex reversal and adrenal insufficiency. J Clin Endocrinol Metab 86:3820-3825

20. Bose HS, Sugawara T, Strauss JF III, Miller WL; International Congenital Lipoid Adrenal Hyperplasia Consortium 1996 The pathophysiology and genetics of congenital lipoid adrenal hyperplasia. N Engl J Med 335:1870-1878

21. Nakae J, Tajima T, Sugawara T, Arakane F, Hanaki K, Hotsubo T, Igarashi N, Igarashi $\mathrm{Y}$, Ishii $\mathrm{T}$, Koda $\mathrm{N}$, Kondo $\mathrm{T}$, Kohno H, Nakagawa $\mathrm{Y}$, Tachibana K, Takeshima Y, Tsubouchi K, Strauss JF III, Fujieda K 1997 Analysis of the steroidogenic acute regulatory protein (StAR) gene in Japanese patients with congenital lipoid adrenal hyperplasia. Hum Mol Genet 6:571-576

22. Katsumata N, Ohtake M, Hojo T, Ogawa E, Hara T, Sato N, Tanaka T 2000 Compound heterozygous mutations in the cholesterol side-chain cleavage enzyme gene (CYP11A) cause congenital adrenal insufficiency in humans. J Clin Endocrinol Metab 87:3808-3813

23. Fujieda K, Tajima T, Nakae J, Sageshima S, Tachibana K, Suwa S, Sugawara T, Strauss JF 3rd 1997 Spontaneous puberty in 46,XX subjects with congenital lipoid adrenal hyperplasia. Ovarian steroidogenesis is spared to some extent despite inactivating mutations in the steroidogenic acute regulatory protein (StAR) gene. J Clin Invest 99:1265-1271

24. Caron KM, Soo SC, Wetsel WC, Stocco DM, Clark BJ, Parker KL 1997 Targeted disruption of the mouse gene encoding steroidogenic acute regulatory protein provides insights into congenital lipoid adrenal hyperplasia. Proc Natl Acad Sci U S A 94:11540-11545

25. Reardon W, Smith A, Honour JW, Hindmarsh P, Das D, Rumsby G, Nelson I Malcolm S, Ades L, Sillence D, Kumar D, DeLozier-Blanchet C, McKee S, Kelly T, McKeehan WL, Baraitser M, Winter RM 2000 Evidence for digenic inheritance in some cases of Antley-Bixler syndrome? J Med Genet 37:26-32

26. Kelley RI, Kratz LE, Glaser RL, Netzloff ML, Wolf LM, Jabs EW 2002 Abnormal sterol metabolism in a patient with Antley-Bixler syndrome and ambiguous genitalia. Am J Med Genet 110:95-102

27. Roth C, Hinney B, Peter M, Steinberger D, Lakomek M 2000 Features of AntleyBixler syndrome in an infant born to a mother with pregnancy luteoma. Eur J Pediatr 159:189-192

28. Abu-Abed SS, Beckett BR, Chiba H, Chithalen JV, Jones G, Metzger D, Chambon P, Petkovich M 1998 Mouse P450RAI (CYP26) expression and retinoic acid-inducible retinoic acid metabolism in F9 cells are regulated by retinoic acid receptor gamma and retinoid X receptor alpha. J Biol Chem 273:2409-2415

29. Morriss-Kay GM, Ward SJ 1999 Retinoids and mammalian development. Int Rev Cytol 188:73-131

30. Muscatelli F, Strom TM, Walker AP, Zanaria E, Recan D, Meindl A, Bardoni B, Guioli S, Zehetner G, Rabl W, Schwarz HP, Kaplan JC, Camerio G, Meitinger T, Monaxo AP 1994 Mutations in the DAX-1 gene give rise to both X-linked adrenal hypoplasia congenita and hypogonadotropic hypogonadism. Nature 372:672-676

31. Kawajiri K, Ikuta T, Suzuki T, Kusaka M, Muramatsu M, Fujieda K, Tachibana M, Morohashi K 2003 Role of the LXXLL-motif and activation function 2 domain in subcellular localization of Dax-1 (dosage-sensitive sex reversal-adrenal hypoplasia congenita critical region on the X chromosome, gene 1). Mol Endocrinol 17:9941004

32. Heery DM, Kalkhoven E, Hoare S, Parker MG 1997 A signature motif in transcriptional co-activators mediates binding to nuclear receptors. Nature 387:733-736

33. Ikeda Y, Swain A, Weber TJ, Hentges KE, Zanaria E, Lalli E, Tamai KT, SassoneCorsi P, Lovell-Badge R, Camerino G, Parker KL 1998 Steroidogenic factor 1 and Dax-1 colocalize in multiple cell lineages: potential links in endocrine development. Mol Endocrinol 10:1261-1272 
34. Kawabe K, Shikayama T, Tsuboi H, Oka S, Oba K, Yanase T, Nawata H, Morohash K 1999 Dax-1 as one of the target genes of Ad4BP/SF-1. Mol Endocrinol 13:1267 1284

35. Lalli E, Melner MH, Stocco DM, Sassone-Corsi P 1998 DAX-1 blocks steroid production at multiple levels. Endocrinology 139:4237-4243

36. Hanley NA, Rainey WE, Wilson DI, Ball SG, Parker KL 2001 Expression profiles of SF-1, DAX1, and CYP17 in the human fetal adrenal gland: potential interactions in gene regulation. Mol Endocrinol 15:57-68

37. Lalli E, Ohe K, Hindelang C, Sassone-Corsi P 2000 Orphan receptor DAX-1 is a shuttling RNA binding protein associated with polyribosomes via mRNA. Mol Cell Biol 20:4910-4921

38. Habiby RL, Boepple P, Nachtigall L, Sluss PM, Crowley WF Jr., Jameson JL 1996 Adrenal hypoplasia congenita with hypogonadotropic hypogonadism: evidence that DAX-1 mutations lead to combined hypothalamic and pituitary defects in gonadotropin production. J Clin Invest 98:1055-1062

39. Takahashi I, Takahashi T, Shoji Y, Takada G 2000 Prolonged activation of the hypothalamus-pituitary-gonadal axis in a child with $\mathrm{X}$-linked adrenal hypoplasia congenita. Clin Endocrinol (Oxf) 53:127-129

40. Fujieda K, Nakae J, Abe S, Tajima T 2000 DAX-1 mutation in adrenal hypoplasia congenita. In: Okomato M, Ishimura Y, Nawata H (eds) Molecular Steroidogenesis. University Academy Press, Tokyo, pp 341-344

41. Seminara SB, Achermann JC, Genel M, Jameson JL, Crowley WF Jr 1999 X-linked adrenal hypoplasia congenita: a mutation in DAX1 expands the phenotypic spectrum in males and females. J Clin Endocrinol Metab 84:4501-4509

42. Tabarin A, Achermann JC, Recan D, Bex V, Bertagna X, Christin-Maitre S, Ito M, Jameson JL, Bouchard P 2000 A novel mutation in DAX1 causes delayed-onse adrenal insufficiency and incomplete hypogonadotropic hypogonadism. J Clin Invest 105:321-328

43. Yu RN, Ito M, Saunders TL, Camper SA, Jameson JL 1998 Role of Ahch in gonadal development and gametogenesis. Nat Genet 20:353-357

44. Jeffs B, Ito M, Yu RN, Martinson FA, Wang ZJ, Doglio LT, Jameson JL 2001 Sertoli cell-specific rescue of fertility, but not testicular pathology, in Dax1 (Ahch)-deficient male mice. Endocrinology 142:2481-2488

45. Zhang YH, Guo W, Wagner RL, Huang BL, McCabe L, Vilain E, Burris TP, Anyane-Yeboa K, Burghes AH, Chitayat D, Chudley AE, Genel M, Gertner JM, Klingensmith GJ, Levine SN, Nakamoto J, New MI, Pagon RA, Pappas JG, Quigley CA, Rosenthal IM, Baxter JD, Fletterick RJ, McCabe ER 1998 DAX-1 mutations map to putative structural domains in a deduced three-dimensional model. Am J Hum Genet 62:855-888

46. Nakae J, Tajima T, Kusuda S, Kohda N, Okabe T, Shinohara N, Kato M, Murashita M, Mukai T, Imanaka K, Fujieda K 1996 Truncation at the C-terminus of the DAX-1 protein impairs its biological actions in patients with $\mathrm{X}$-linked adrenal hypoplasia congenita. J Clin Endocrinol Metab 81:3680-3685

47. Nakae J, Abe S, Tajima T, Shinohara N, Murashita M, Igarashi Y, Kusuda S, Suzuk J, Fujieda K 1997 Three novel mutations and a de novo deletion mutation of the DAX-1 gene in patients with X-linked adrenal hypoplasia congenita. J Clin Endocrinol Metab 82:3835-3841

48. Peter M, Viemann M, Partsch CJ, Sippell WG 1998 Congenital adrenal hypoplasia: clinical spectrum, experience with hormonal diagnosis, and report on new point mutations of the DAX-1 gene. J Clin Endocrinol Metab 83:2666-2674

49. Reutens AT, Achermann JC, Ito M, Ito M, Gu WX, Habiby RL, Donohoue PA, Pang S, Hindmarsh PC, Jameson JL 1999 Clinical and functional effects of mutations in the DAX-1 gene in patients with adrenal hypoplasia congenita. J Clin Endocrinol Metab 84:504-511

50. Ito M, Yu R, Jameson JL 1997 DAX-1 inhibits SF-1-mediated transactivation via a carboxy-terminal domain that is deleted in adrenal hypoplasia congenita. Mol Cell Biol 17:1476-1483

51. Achermann JC, Ito M, Silverman BL, Habiby RL, Pang S, Rosler A, Jameson JL 2001 Missense mutations cluster within the carboxyl-terminal region of DAX-1 and impair transcriptional repression. J Clin Endocrinol Metab 86:3171-3175

52. Lalli E, Bardoni B, Zazopoulos E, Wurtz JM, Strom TM, Moras D, Sassone-Corsi P 1997 A transcriptional silencing domain in DAX-1 whose mutation causes adrenal hypoplasia congenita. Mol Endocrinol 11:1950-1960

53. Lehmann SG, Lalli E, Sassone-Corsi P 2002 X-linked adrenal hypoplasia congenita is caused by abnormal nuclear localization of the DAX-1 protein. Proc Natl Acad Sci U S A 99:8225-8230
54. Lehmann SG, Wurtz JM, Renaud JP, Sassone-Corsi P, Lalli E 2003 Structurefunction analysis reveals the molecular determinants of the impaired biological function of DAX-1 mutants in AHC patients. Hum Mol Genet 12:1063-1072

55. Bassett JH, O'Halloran DJ, Williams GR, Beardwell CG, Shalet SM, Thakker RV 1999 Novel DAX1 mutations in X-linked adrenal hypoplasia congenita and hypogonadotropic hypogonadism. Clin Endocrinol (Oxf) 50:69-75

56. Vilain E, Le Merrer M, Lecointre C, Desangles F, Kay MA, Maroteaux P, McCabe ER 1999 IMAGe, a new clinical association of intrauterine growth retardation, metaphyseal dysplasia, adrenal hypoplasia congenita, and genital anomalies. J Clin Endocrinol Metab 84:4335-4340

57. Krude H, Biebermann H, Luck W, Horn R, Brabant G, Gruters A 1998 Severe early-onset obesity, adrenal insufficiency and red hair pigmentation caused by POMC mutations in humans. Nat Gene 19:155-157

58. Jackson RS, Creemers JW, Ohagi S, Raffin-Sanson ML, Sanders L, Montague CT, Hutton JC, O'Rahilly S 1997 Obesity and impaired prohormone processing associated with mutations in the human prohormone convertase 1 gene. Nat Genet 16:303-306

59. Cohen LE, Radvick S 2002 Molecular basis of combined pituitary hormone deficiencies. Endocr Rev 23:431-442

60. Lamolet B, Pulichino AM, Lamonerie T, Gauthier Y, Brue T, Enjalbert A, Drouin J 2001 A pituitary cell-restricted T box factor, TPIT, activates POMC transcription in cooperation with Pitx homeoproteins. Cell 104:849-859

61. Pulichino AM, Vallette-Kasic S, Couture C, Gauthier Y, Brue T, David M, Malpuech G, Deal C, Van Vliet G, De Vroede M, Riepe FG, Partsch CJ, Sippell WG, Berberoglu M. Atasay B, Drouin J 2003 Human and mouse TPIT gene mutations cause early onset pituitary ACTH deficiency. Genes Dev 17:711-716

62. Clark AJ, Weber A 1998 Adrenocorticotropin insensitivity syndromes. Endocr Rev 19:828-843

63. Tsigos C, Arai K, Hung W, Chrousos GP 1993 Hereditary isolated glucocorticoid deficiency is associated with abnormalities of the adrenocorticotropin receptor gene. J Clin Invest 92:2458-2461

64. Metherell LA, Chapple JP, Cooray S, David A, Becker C, Ruschendorf F, Naville D, Begeot M, Khoo B, Nurnberg P, Heubner A, Cheetham ME, Clark AJL 2005 Mutations in MRAP, encoding a new interacting partner of the ACTH receptor, cause familial glucocorticoid deficiency type 2. Nat Genet 37:166-170

65. Tullio-Pelet A, Salomon R, Hadj-Rabia S, Mugnier C, de Laet MH, Chaouachi B, Bakiri F, Brottier P, Cattolico L, Penet C, Begeot M, Naville D, Nicolino M, Chaussain JL, Weissenbach J, Munnich A, Lyonnet S 2000 Mutant WD-repeat protein in triple-A syndrome. Nat Genet 26:332-335

66. Sandrini F, Farmakidis C, Kirschner LS, Wu SM, Tullio-Pelet A, Lyonnet S, Metzger DL, Bourdony CJ, Tiosano D, Chan WY, Stratakis CA 2001 Spectrum of mutations of the AAAS gene in Allgrove syndrome: lack of mutations in six kindreds with isolated resistance to corticotropin. J Clin Endocrinol Metab 86:5433-5437

67. Cronshaw JM, Matunis MJ 2003 The nuclear pore complex protein ALADIN is mislocalized in triple A syndrome. Proc Natl Sci U S A 100:5823-5827

68. Peterson P, Pitkanen J, Sillanpaa N, Krohn K 2004 Autoimmune polyendocrinopathy candidiasis ectodermal dystrophy (APECED): a model disease to study molecular aspects of endocrine autoimmunity. Clin Exp Immunol 135:348-357

69. Arlt CW, Allolio B 2003 Adrenal insufficiency. Lancet 361:1881-1893

70. The Finnish-German APECED Consortium 1997 Autoimmune polyendocrinopathycandidiasis-ectodermal dystrophy. An autoimmune disease, APECED, caused by mutations in a novel gene featuring two PHD-type zinc-finger domains. Nat Genet 17:399-403

71. Nagamine K, Peterson P, Scott HS, Kudoh J, Minoshima S, Heino M, Krohn KJ, Lalioti MD, Mullis PE, Antonarakis SE, Kawasaki K, Asakawa S, Ito F, Shimizu N 1997 Positional cloning of the APECED gene. Nat Genet 17:393-398

72. Ramsey C, Winqvist O, Puhakka L, Halonen M, Moro A, Kampe O, Eskelin P, Pelto-Huikko M, Peltonen L 2002 Aire deficient mice develop multiple features of APECED phenotype and show altered immune response. Hum Mol Genet 11:397409

73. Tait KF, Gough SC 2003 The genetics of autoimmune endocrine disease. Clin Endocrinol 59:1-11

74. Dittmar M, Kahaly GJ 2003 Polyglandular autoimmune syndromes: immunogenetics and long-term follow-up. J Clin Endocrinol Metab 88:2983-2992 